\title{
“When I Am a President of Guinea": Resettled Refugees Traversing Education in Search of a Future
}

\section{Citation}

Dryden-Peterson, Sarah, and Celia Reddick. 2017. 'When I Am a President of Guinea': Resettled Refugees Traversing Education in Search of a Future." European Education 49 (4) (October 2): 253-275.

\section{Published Version}

doi:doi.org/10.1080/10564934.2017.1344865

\section{Permanent link}

http://nrs.harvard.edu/urn-3:HUL.InstRepos:34694924

\section{Terms of Use}

This article was downloaded from Harvard University's DASH repository, and is made available under the terms and conditions applicable to Open Access Policy Articles, as set forth at http:// nrs.harvard.edu/urn-3:HUL.InstRepos:dash.current.terms-of-use\#OAP

\section{Share Your Story}

The Harvard community has made this article openly available.

Please share how this access benefits you. Submit a story.

\section{Accessibility}


Title: "When I am a President of Guinea": Resettled Refugees Traversing Education in Search of a Future

Authors: Sarah Dryden-Peterson and Celia Reddick ${ }^{1}$

Submission: Special Issue of European Education on Internationalization in conflictridden societies and within migrant populations

\section{Contact Information}

Sarah Dryden-Peterson (Corresponding Author)

Harvard Graduate School of Education (Institutional Affiliation)

6 Appian Way

Cambridge, MA 02138

Tel: (617) 435-2344

Email: sarah_dryden-peterson@gse.harvard.edu

\section{Acknowledgements}

The authors wish to thank Moussa for sharing with us his insights, hopes and preoccupations; Sulayman, Shamim, and the faculty and staff of Moussa's school for their support of this project; Sara Lawrence-Lightfoot, Vidur Chopra, and Anastasia Aguiar for critical and insightful feedback on earlier drafts; and Eleanor O'Donnell Weber for analysis of important related literature.

\section{Funding}

The authors express thanks for generous funding from the National Academy of Education/Spencer Foundation and the Harvard Graduate School of Education.

\section{Disclosure Statement}

The authors hold no financial interest or benefit arising from the direct applications of this research.

\section{Keywords}

Refugee education, refugee resettlement, post-education opportunities

\section{Author Bios}

Sarah Dryden-Peterson is an Associate Professor at the Harvard Graduate School of Education. She leads a research program that focuses on the connections between education and community development, specifically the role that education plays in building peaceful and participatory societies. Her work is situated in conflict and postconflict settings in sub-Saharan Africa and with African Diaspora communities. She is concerned with the interplay between local experiences of children, families, and teachers and the development and implementation of national and international policy. Her research reflects connections between practice, policy, and scholarship and is strengthened through long-term collaborations with UN agencies, NGOs, and communities. Her recent research is published in Educational Researcher, Comparative Education Review, and Curriculum Inquiry. Raised in Toronto, Canada, Dryden-Peterson 
taught primary school in Madagascar, South Africa, and the United States and founded education non-profits in South Africa and Uganda.

Celia Reddick is a doctoral student at the Harvard Graduate School of Education in the Cultures, Institutions and Societies concentration. She is interested in educational policies for displaced youth, and the relationship between education and conflict. She serves on the editorial board of the Harvard Educational Review and as a member of the Teaching Team for the course Education in Armed Conflict. Prior to pursuing doctoral work, she taught high school English as a Second Language through the NYC Teaching Fellows Program and worked with teachers and medical clinicians in Uganda, Rwanda and Haiti. 


\title{
"When I am a President of Guinea": \\ Resettled Refugees Traversing Education in Search of a Future
}

\begin{abstract}
This article explores how resettled refugees' aspirations cultivated through education collide with post-schooling realities. We find that post-graduation barriers of financial insecurity, housing insecurity, violence and discrimination, and lack of critical awareness of unequal opportunity structures stand in the way of resettlement aspirations. We discuss how teachers and schools might be re-tooled to equip refugee students with more and different skills to navigate post-graduation situations.
\end{abstract}

\section{Introduction}

As a $10^{\text {th }}$ grade student, Moussa ${ }^{2}$ drew a poster, carefully and in pencil. It displayed the finely etched faces of two black leaders, then-presidential hopeful Barack Obama and Martin Luther King, Jr. A refugee from Guinea, West Africa, Moussa often spoke of his plans to follow in the footsteps of these great men. He came to school dressed the part - in a suit - carrying these dreams and those of his family. Now 23 years old, he wears faded light blue jeans and a matching denim jacket with shiny white sneakers, sporting short, straggly tufts of a beard and a flattop haircut.

Moussa arrived in New York City in 2006 at the age of thirteen. Guinea - the home with which he distinctly identifies - had fallen into violence just as had Sierra Leone, the place of his birth. When Moussa was a baby, his family fled the eleven-year civil war in Sierra Leone, hoping to find safety in neighboring Guinea. As Moussa 
explained, "we thought our life would be much better, not knowing that there were a whole new set of challenges to face.” By 2000, Guinea was experiencing its own violence and instability, which refugees were publically accused of fomenting, with the years since marked by contested elections and attempted coups (Marchal, 2002). A future in Guinea no longer seemed secure to Moussa's family, and they began to plan for yet another, perhaps more permanent, exile.

Moussa's father responded to early challenges that his family faced in Guinea. Moussa explained, "it was really hard for us to go to school...We're running from a war...We barely had electricity, barely, so you know my father, he had to do something about it, so he came here." Ten years before Moussa's arrival in the United States, his father earned an asylum visa, leaving Guinea for New York City with a promise that, soon, he would bring his second wife and three sons, including then-toddler Moussa. During the years they were apart, Moussa's father sent money back to ensure Moussa's continued schooling.

Most of Moussa's refugee peers studied "under the mango trees" while in Guinea, isolated in refugee camps (Jones, 2006; Shepler, 2011). Moussa did not. Benefiting from the $\$ 300$ a month his father sent from New York, Moussa attended one of the best private schools in Conakry, Guinea's capital, where he was often first in his class. He spoke Fulani at home, but at school he spoke French, joining a small transnationally-oriented elite (Anderson-Levitt \& Diallo, 2003; Benson \& Lynd, 2011). Moussa compared his education to that of other children in the neighborhood: he did not have to attend overcrowded classes as they did. He did, however, spend his evenings perched at gas 
stations and the airport to scratch out his homework under the electric light his home did not have.

Upon arrival in New York, Moussa joined a small high school, specifically focused on meeting the academic, linguistic, and socioemotional needs of newly arrived immigrants and refugees, like him. Moussa excelled in that space, quickly learning English while retaining his home language, gaining the respect of his teachers, taking on a leadership role in an afterschool program, and graduating from high school in 2010 with high grades. Yet by 2016, Moussa's education and future prospects had stagnated. Despite the expectations of his family and his own goals for himself, financial constraints, structural barriers including discrimination, and isolation from upwardly mobile networks have truncated his continued educational path and landed him in what he sees as dead-end jobs where he is not learning or making enough to support his family. Once again comparing himself to those in Guinea, he explained, "I know other people back home who still don't [go to school] - and I feel like them.” Moussa wants to complete his own education and be a leader in helping young people back home also secure an education so that they might build their futures. Yet his own education has not led him toward the future he imagined.

Through a portrait of Moussa, this article investigates the ways in which refugees' educational experiences interact with their post-educational experiences. We ask, in what ways does education equip refugee students in the United States to create their futures post-graduation? In this way, we focus not only on how schools and teachers meet the needs of refugee students in their classrooms, but how that education serves refugees once they leave school. While our study is set in the U.S., it is relevant for other refugee- 
hosting nation-states, especially in Europe, in which refugees pursue education and seek out post-graduation futures.

\section{Conceptual Framework: Refugee Education and the Parameters of Hope}

\section{Resettlement: Refugees' Ultimate Hope}

Refugees are individuals who have crossed an international border due to a wellfounded fear of persecution (UNHCR, 2010). Most refugees fleeing conflict in Sierra Leone in the 1990s, from which Moussa initially sought exile, became refugees in neighboring Guinea and Liberia. This localized exile is the global pattern. Eighty-six percent of the world's refugees live in host countries that neighbor their conflict-affected countries of origin (UNHCR, 2014a).

Less than one percent of refugees globally settle in countries with high Gross National Income (GNI) per capita, a process called "resettlement" (UNHCR, 2014b). In 2014, the United States resettled 267,000 refugees (UNHCR, 2015), the most of any country, about one third of whom were school-aged children (Capps \& Newland, 2015, p. 9). A refugee who is resettled arrives in the resettlement country having already been approved for asylum. Resettlement is thus a "permanent" or "durable" solution to the uncertainty of exile, yet it is unavailable to the vast majority of refugees globally (see, for example, Nunn, McMichael, Gifford, \& Correa-Velez, 2015). In 2015, the average length of exile without a durable solution was 10.3 years (Devictor \& Do, 2016).

Resettlement, on the other hand, guarantees a pathway to citizenship. In the United States, for example, resettled refugees have "conditional status" for one year before receiving permanent residency and eligibility for naturalization after five years. Among refugees in exile, resettlement is therefore widely perceived as the ultimate hope 
(see, for example, Rawlence, 2016; Sévigny, 2012; Swing, 2017). Aside from seeking long-term security, one of the principal reasons that refugees seek resettlement is so that their children can be educated for a "better future" (see, for example, Dryden-Peterson, 2017b).

\section{Supporting Refugees in U.S. Schools}

Most refugee young people who are resettled to the United States have had previous educational experiences in their countries of origin, their countries of first asylum, or both. While these educational experiences vary widely, they are marked by continual learning of new languages of instruction that often prevent content mastery; teacher-centered pedagogy and lack of familiarity with U.S. classroom norms of participation and discussion; and discrimination in school settings that can engender lack of trust in school-based relationships (Dryden-Peterson, 2015). Refugee young people also exhibit high levels of trauma exposure, post-traumatic stress disorder, and other mental health challenges that require targeted interventions (Betancourt, Meyers-Ohki, Charrow, \& Tol, 2013; Betancourt et al., 2012; McBrien, 2005).

In addition to better understanding their pre-resettlement experiences, several recent studies have identified ways in which U.S. schools can meet the needs of their refugee students, including through specifically targeted language instruction, relational supports, pedagogy, and curriculum. These 'successful' schools, which are specifically designed to serve refugee and immigrant newcomers, used languages as a resource, engaging in "translanguaging” practices (GarcÍa \& Wei, 2014), by which they encouraged students to use multiple languages toward both content mastery and social 
belonging. At the same time, they recognized refugee students' aspirations for English fluency and prioritized that goal (Bajaj \& Bartlett, 2017; Mendenhall, Bartlett, \& Ghaffar-Kucher, 2017). Relationships of care and support spurred refugees' connection to and investment in school as well as their academic performance (Bartlett, Mendenhall, \& Ghaffar-Kucher, Forthcoming; Dryden-Peterson, 2017a; Mendenhall et al., 2017). Pedagogies of heterogeneous groupings of students, whereby students could serve as resources to one other, as well as an intensive focus on differentiated instruction that reflected students' experiences also contributed to refugee students' success in school (Bajaj \& Bartlett, 2017; Mendenhall et al., 2017). At the same time, given preresettlement educational experiences, many refugee students described challenges with the learner-centered instruction they encountered in U.S. schools (Mendenhall et al., 2017).

As we argue elsewhere, the curriculum of refugee education importantly engages with deliberation about the nature of knowledge, reflection on the purposes of education, and engagement with politics and power structures (Dryden-Peterson, 2017b). Along these lines, we agree with Bajaj and Bartlett (2017) about the need to problematize the purposes of education for resettled refugees, in particular opening up possibilities that the goals of schooling may not be exclusively national. While the notion of "global citizenship education" is appealing in this context, its application in the U.S. is often selfreferential, geared toward the place of this nation-state in the world (Goren \& Yemini, 2017). Further, for marginalized young people, teachers in Northern Ireland and Israel found that global citizenship education, although theoretically promising, was not viable given sociopolitical and geopolitical restrictions these students face (Goren \& Yemini, 
2015; Reilly \& Niens, 2014). Bajaj and Bartlett argue that a "critical transnational curriculum" that builds on the transnational nature of refugee students' identities, sense of belonging, and imagined futures, which may be outside the U.S., offers possibilities for "multidirectional aspirations" (2017). They note an important gap in terms of how to engage in educational practices that reflect these aspirations.

Post-education opportunities for refugees: the parameters of hope

Recent studies identify schools and practices that solidify refugee students' beliefs in the power of education as a route to opportunity in their sites of resettlement (Bajaj \& Bartlett, 2017; Mendenhall et al., 2017). They also reveal the need for a more nuanced understanding of the ways in which the skills and knowledge that refugees gain, even from schools identified as most successful, can be applied to their post-graduation futures. In particular, Bajaj and Bartlett identify the "constrained agency of newcomer youth, many of whom have fled violence and carry significant trauma from the home countries only to arrive and live in poverty at the margins of urban US centres" (2017, p. 26). Although they described three schools that "helped students not only develop a critical consciousness about social inequalities in the US and beyond, but also respond to inequalities through political action," they point to the challenges of critical pedagogy connected to action when living in the margins (2017, p. 31).

Similarly, Duncan-Andrade argues that schools serving poor students promulgate "false hope," hope that is apolitical and ahistorical and that overlooks inequalities pervasive both inside and outside of school and imagines that students will encounter equal opportunity structures (2009). False hope ignores the "organized abandonment" 
(Gilmore, 2011) by the nation-state of marginalized individuals and communities, including refugees and other migrants. It is not unique to the United States, with parallels in Europe (Alba \& Foner, 2014; Auernheimer, 2005; Kowalczyk, 2010). In the context of post-conflict transition in Guatemala, it manifests in what Bellino calls "wait citizenship," in that productive forms of citizenship are promised through education but conditions under which politically and economically marginalized individuals or groups can realize it are illusive (2017). Its antidote, Duncan-Andrade argues, is "critical hope," composed of resources and networks that support and nurture students, inspire in them courage to pursue painful paths, and solidarity to transform systems and structures (2009). Can this kind of praxis of transforming the world through action and reflection (Freire, 1994) prepare students for post-graduation experiences?

Current studies of education of resettled refugees are generally school-based, ending with graduation from secondary school. We are interested in how aspirations cultivated by refugee students in primary and secondary schools in the United States collide with post-schooling realities. In this article, we thus examine how one refugee student, Moussa, balances his aspirations - born in exile and further cultivated through his schooling in the United States - with the conditions in which he lives and works postgraduation. Our line of thinking echoes a backward-mapping approach (Dyer, 1999). We examine Moussa's experiences both in school and upon graduation to illuminate how they intersect as he seeks to create his future. In the Discussion section, we explore how educators and schools might better equip their refugee students to meet these challenges and opportunities, especially in the segregated and unequal communities in which they live. 


\section{Methodology}

In our search to understand the ways in which refugees navigate education and post-education opportunities in exile, we chose a methodology that would allow us to probe deeply into complex and dynamic processes that cannot be captured at one moment in time (see also, Dryden-Peterson, 2010, 2011, 2017b). We employed portraiture, which is a social science methodology that seeks to pursue, understand, and convey the "authority, knowledge, and wisdom" of the perspectives and experiences of research participants (Lawrence-Lightfoot \& Davis, 1997, pp. xv, 103). Central to this methodology is intense engagement of the researcher and the participants in coconstruction of knowledge. Stemming from this constructivist epistemology, portraiture does not rely on singular methods (e.g., interviews, participant observation, surveys) but instead employs many methods and forms of data, selected based on what can inform the research questions under investigation.

Further, portraiture focuses, intently, on what can be excavated through relationships. It is through the empathy and openness of a relationship - rather than a research interaction - that the researcher can connect with participants in order to uncover meaning-making, decision-making, and vulnerabilities. Relationships also allow the researcher to "pursue the silences" (Lawrence-Lightfoot, 2005, p. 12) that often surround troubling and complex phenomena. Given silences around issues of discrimination, nativism, belonging, and agency in the U.S., and elsewhere, actively pursuing these silences is essential to the research questions that frame this study.

We chose to focus on Moussa because of his particularly determined stance toward education, and his early interest in leadership. More is understood about the 
factors that inhibit school success for refugees than is understood about strategies that enable success (see, for example, Dryden-Peterson, 2015; Hatoss \& Huijser, 2010; McBrien, 2005); further, more is understood about the ways in which failure in schools limits possibilities for community engagement and early employment experiences for refugee youth than ways in which school success enables opportunities (see, for example, Lamba, 2003; Nunn et al., 2015). Our interest in this inquiry is also deeply personal: both authors taught refugee students in middle schools and high schools in the U.S. and felt inadequate in their abilities to meet their students' academic, socioemotional, and aspirational needs. As researchers, we seek to build the kind of actionable theories and knowledge that, as teachers, we craved.

We thus focus on how a successful student navigated his educational trajectory and post-school opportunities and barriers. In particular, in seeking to understand how refugees navigate education and build their futures, we chose to analyze the experiences of an individual who 'did everything right' according to the metrics that schools set in place. Moussa received good grades, including a 90 on his U.S. History and Government Regents exam and an 87 on his Global History and Geography Regents exam; he was well-respected by his teachers; he graduated; he stayed out of trouble; his father was present and supportive. He also attended a high school that was specifically designed to meet the educational needs of immigrant and refugee newcomers like him. If charting a pathway into a post-secondary school future proved challenging for a student like Moussa, it is likely that this process is challenging, and perhaps even more so, for other refugee students. In this way, Moussa represents a "critical case," designed to allow for this type of logical deduction (Flyvbjerg, 2006). 
Central to our design was building on a long-term relationship between one of the authors, Reddick, and our research participant, Moussa. Moussa was a $10^{\text {th }}$ grade student in Reddick's $9^{\text {th }}$ and $10^{\text {th }}$ mixed-grade English class at a high school for newcomers to the U.S. As a New York City Teaching Fellow, Reddick taught Moussa for one year, and during this time also met his father on multiple occasions during parent-teacher conferences and at school events. Moussa and Reddick, together with other students, also engaged in literacy activities during and after school hours, discussed college preparation, and visited a college in a neighboring state. When she moved to Uganda, Moussa and his classmates collected clothes and materials for students there, maintaining the relationship despite physical distance. When Reddick returned to New York City to work in a sister school for new arrivals within the same network, she attended the graduation ceremony at Moussa's school, and maintained connections with his high school cohort through Facebook and other school networks.

Through this existing relationship, we were able to collect data that spanned both the past and the present and particularly probed details of earlier moments in Moussa's educational trajectory that may have remained opaque to us if building a research relationship at one moment in time. For example, knowing that Moussa wore a suit daily when he was in high school allowed us to probe on the processes of his decision-making to change attire, toward jeans and a t-shirt, and the surrounding events, experiences, and relationships that he saw as meaningful to these processes and decisions.

In this article, we draw on multiple sources of data, including semi-structured interviews with the participant; participant observation; interviews with people important to Moussa, including his high school peers, family members, co-workers, and former 
teachers; and artifacts, such as of Moussa's schoolwork, and document analysis, such as of the school's website and related videos. The original dataset includes 15 hours of interviews; two days of participant observation in settings that Moussa identified as important to him, such as his mosque, his workplace, and his home; a walk through his neighborhood as a way to elicit further narrative, including related to the school he once attended; and on-going text messages related to events unfolding in his life that related to the topic of inquiry and that he chose to discuss. Our analysis also draws on insights gained over Reddick's ten-year relationship with Moussa.

We followed Moussa's lead on data sources that were salient to him as well as actively opened up conversations that were important to our inquiry, based on previous research and our reading of the literature. For example, Moussa put forth his portfolio of work from high school as a source of data, illuminating for us the kind of work of which he was proud. When Moussa created the opportunity to speak with his workplace mentor, we took it. This encounter opened up conversations with Moussa about his own similarities and differences to this man and to the racial and class groups the man identified with, allowing us to learn more about Moussa's identity from this “boundary work" (Lamont \& Swidler, 2014).

Where possible, each interview was audiorecorded and later transcribed. In instances where recording was impractical and uncomfortable - when walking through Moussa's neighborhood in heavy rain, when sitting in his living room with his stepmother and brother with Guinean news on the television, when talking at the bar of the noisy restaurant in which he worked before moving to a back room - we rely on extensive notes, often verbatim, taken both during and after the conversations. Following 
each day of interviewing, Reddick wrote impressionistic field notes of what she had heard and witnessed, further engaging in initial analyses through sorting the notes into emerging themes.

The authors coded the interview and fieldnote data in Atlas.ti. We took a grounded approach in our analysis, arriving at a set of codes that emerged from the data. For example, codes included "discrimination," "preparing for a future," "language," "relationships," and "expectations," among others. At various stages throughout the analysis, the authors also checked the findings with Moussa through text messages and in-person conversations, refining the analysis and adding to the data through these conversations; we further corroborated details related to the school with current and former school faculty and staff.

We do not present Moussa's case as one to be reified, but instead as one of many possible trajectories of refugees' navigating education. It is within the nuance of the particulars of his experiences that we generate important themes that resonate across our broader research on refugee education and that provide important ideas for further research. Our focus on one individual is a core strength of our design as it enables a deep probing of the kinds of structures with which he interacts; the types of decisions he faces; and the ways in which his educational experiences have, over time and in complex ways, shaped and are shaping his future.

\section{Findings}

In this section, we present and interpret the study's findings through a portrait of Moussa's experiences in high school and in the five years since that time. We divide our 
analysis into five themes: building a future, excluded from the dream, a space to live the expected life, a permanent exile, and relationships of support and hope. Through these themes, we examine the many established practices that Moussa's school adopted to foster school success for refugees. We further explore the ways in which these practices that foster success in school may connect - or not - with success after graduation.

We find that Moussa's small and caring school environment differed from his experiences outside of school both during his schooling and post-graduation. We demonstrate that his post-graduation experiences do not align with what he thought his schooling prepared him for, both in terms of future education and employment. The relationships he has cultivated since graduation point to learning and skills that he did not develop in school, particularly in facing and addressing material constraints of poverty and discrimination. We present these findings with the goal of identifying overlaps and misalignments between Moussa's school-based learning and his post-graduation outcomes. At the intersection of the overlaps and misalignments lie specific strategies for teachers and schools to better prepare their refugee students to navigate post-graduation futures, which we address explicitly in the Discussion section that follows.

\section{Building a future}

Moussa still keeps his early assignments from the small public high school for new arrivals where he landed upon his resettlement to the United States at age 13. He had originally hoped to enroll at the more established school for new arrivals down the street, but it had reached its cap for enrollment. He ended up at its smaller sister school, as a member of the first class. This school was one of a now expanding number of schools specifically targeted to serve newly arrived immigrant and refugee young people (see 
also, Bajaj \& Bartlett, 2017; Bartlett \& García, 2011; Mendenhall et al., 2017). The school aimed to give newcomers 'the support they need to reach their goals, and the pedagogical rigor necessary for them to achieve academic outcomes that meet and exceed those of their peers' (paraphrased from school website in order to maintain anonymity).

The school building itself is beige, squat and long, with small blue doors and blue trim around the windows, originally intended for elementary school students. Moussa pointed out, fondly, the spot in front of the school under a leafy tree where his father dropped him each morning. At home, Moussa has carefully kept his school assignments, which track his learning, with other artifacts from his years at school. In this bundle are handwritten essays from the small high school and, later, typed documents from his one year at City Community College (CCC), in particular an essay for which he earned an A. Moussa tries not to brag as he points out the good grades he has received over the years.

English-language learning is the dominant focus of refugee education programming in the U.S., and it was the focus at Moussa's high school as well. His new school was situated within a collaborative project-centered learning approach, different from his school in Guinea, which he described as “more of a telling than you seein' the reality." Teachers encouraged students to use their home languages, to talk together with other students who shared linguistic backgrounds to make meaning and understand content, and to strengthen their speaking and reading skills in various languages. As a memento of this time, Moussa has kept the Fulani/English dictionary which his first English teacher, Ms. Mary, helped him make to support him in this English language environment. It is peppered with illustrations and words in two languages, with notes in French here and there. As they engaged in these "border-crossing communicative 
practices" (Hornberger \& Link, 2012, p. 263) that drew on their linguistic strengths, Moussa and his peers worked both toward critical conceptual learning and English language proficiency.

Despite these efforts to use home languages, Moussa still felt alienation, a phenomenon echoed in the literature (Bigelow, 2010; Buck \& Silver, 2012). The transnationalism he thought French poised him for was of little use in New York City. Like 62 percent of refugee arrivals to the U.S., Moussa arrived in New York with little English (Migration Policy Institute, 2014, p. 14), while quickly realizing it would be the currency of his future (see also, McBrien, 2005). He described a fight when he was goaded by a classmate but unable to explain himself, and thus bore the brunt of the punishment. "Now that I speak English," he explained with a smile, "I always let people know how I feel and that makes me feel great. It really do."

Relationships with his peers allowed Moussa to begin to tool himself to navigate his new context of exile. At his school, Moussa met other students who had fled conflict and violence. Many were West African, and some were of different ethnic groups historically in conflict with the Fulani, his ethnic group. But in a different geographic space, they found a way to maintain peace. He and Sulayman, a student from the historically powerful Mandinka ethnicity and a national of neighboring Liberia, who had himself fled to Guinea before resettlement in the U.S., found closeness in a mutual regard for the suffering they each experienced before their arrival. Moussa said, "He respects me and I respect him, him coming from Liberia, you know, going through a war, and I feel bad for him and he feel bad for me, you know? We all went through the same thing, so 
there was no reason for us to start another war at a peaceful country, so we like 'You know what man? Let's be friends'."

At his school, Moussa also found caring teachers, forged relationships with peers, and felt successful in his learning. A City University of New York cohort study released just before Moussa started school in New York confirmed that students in schools like his graduate at higher rates than New York City students and more than double the rate of other English Language Learners in New York City (Fine, Stoudt, \& Futch, 2005). During the time Moussa attended, 85 percent of black students at his school graduated within four years, compared to 60 percent of black students city-wide in the same year (New York City Department of Education, 2017).

At the time, Moussa thought his school was a place where he and his fellow students were preparing for success in the world beyond its walls. A video of the school, made around the year of Moussa's graduation, expressed these broader sentiments clearly: "We are not perfect, but we are getting better" and "we are going to study hard to make our dreams come true." Yet the world beyond the school did not much resemble Moussa's experiences in that beige building. Many of the newcomer students had come from relatively privileged backgrounds. Simone's mother was a doctor in Guinea. David had lived transnationally between France and West Africa. At the same time, among the students were also Kadidia, who had fled Mali, and Rosa, a Garifuna student from Honduras, who had been excluded from school before arriving in New York City and thus, as a teenager, was still struggling to learn the letters of the alphabet. This bifurcation in previous education and economic class is also common among refugees to the U.S. more generally, with high school graduation rates for refugees over the age of 25 varying 
widely among country of origin, between 40 and 95 percent (Migration Policy Institute, 2014, p. 17). Despite divergent pre-migration socio-economic and educational experiences, however, Moussa and his peers soon realized their common situation in the United States. Indeed, pervasive poverty is a stark reality for refugee children: 67 percent of refugees arriving when Moussa did, between 2006 and 2011, lived below 200 percent of the federal poverty threshold, compared to 33 percent of the U.S.-born population (Migration Policy Institute, 2014, pp. 20-21).

Moussa's school met the metrics from the literature of practices that foster refugee student success in schools, which we described above: use of languages as a resource; the integration of English language and content instruction; peer and teacher relationships based on care and support; and pedagogy that includes heterogeneous groupings. Were these practices productive for refugee students' lives post-graduation?

The teachers at Moussa's school struggled with the challenge of providing Moussa and his classmates an education that would serve them in their long-term contexts of poverty. In keeping with trends nationwide for poor black and brown students, Moussa's teachers were young and new to the profession, most in their first and second years of teaching (Darling-Hammond, 2010). A quarter entered through the New York City Teaching Fellows Program, an alternative certification education program that, like many such programs, places new teachers in marginalized high schools. The pernicious effects of inexperienced teachers on student achievement are increasingly well-understood (Darling-Hammond, 2010, p. 144). Another consequence of young, inexperienced teachers and alternative teacher certification programs is high turnover rates (United States Department of Education, 2016). Since Moussa began at this school 
eleven years ago, all of the original teachers have left the school, and many within their first five years in the profession.

Again echoing national trends (United States Department of Education, 2016), although all of the students were black and brown, the teaching staff was not. Rather, although the principal and guidance counselor were both second generation immigrants from Latin America; the coordinator of special programs, a first generation immigrant from Jamaica; and the parent coordinator, a first generation immigrant from Senegal, the year that Moussa was in $10^{\text {th }}$ grade, eight out of twelve teachers at the school were U.S.born white Americans. These teachers had grown up, attended school, and pursued opportunities for higher education and employment in circumstances very different from those facing the students they now taught. Despite being committed to addressing inequalities, they struggled to see and understand the challenges their students would face upon graduation. Further, in the author's reflection on her own work at the school, she and other teachers largely failed to communicate with their students in ways that acknowledged the structural barriers they would face even if they got good grades, graduated, acted against inequalities, and stayed out of trouble, or to use curricula and pedagogy that prepared their students to counter these persistent barriers. Despite their best intentions, many of these new educators perpetuated a kind of false hope among themselves and with their students.

While the teachers recognized the socioemotional and academic needs of students like Moussa, and cultivated strong and caring relationships with them, most were unprepared to adequately address these needs. Many of these students had either lived away from their parents for years and sometimes decades, and only recently reunited with 
their parents in the U.S. Others were newly separated from those they left at home or lost in war. Few educators had the training to provide the necessary socioemotional supports, and the school's single guidance counselor was vastly overburdened by the scope of the students' needs. Furthermore, many students were overaged. Sulayman, who was originally from Liberia, had a visa that claimed he was many years younger than he in fact was. His "official” age allowed him to meet the age cut-off for attending school in New York, but he dropped out of school in $12^{\text {th }}$ grade, knowing that he would not be permitted to repeat the math Regents exams he had been unable to pass. Sulayman was attending school for the first time, having faced extensive barriers in Liberia due to ongoing violence. He was in fact in his mid-20s and contending with the first stages of literacy and numeracy alongside Shamim, a thirteen-year-old from Bangladesh whose visa claimed he was sixteen. These inaccuracies in their visas, quite intentionally sought, meant that the newcomers could access public schooling. The heterogeneity of students' academic and linguistic abilities, age, ethnicities, and more were an "educational resource" (Bajaj \& Bartlett, 2017, p. 29), particularly as related to their peer relationships and peer teaching. Yet the wide span of developmental stages also made the work of differentiating instruction especially complicated for the basic skills that Moussa craved, and particularly for young educators in their first years of teaching.

\section{Excluded from the dream}

Other research echoes the benefits Moussa experienced of bringing newcomer students together in small schools, including a sense of safety and belonging and relationships with peers who shared similar experiences. That literature is silent on some 
of the challenges of this isolation, which Moussa experienced. While Moussa's school enabled him to build relationships with caring teachers who had very different racial and socio-economic experiences than he did, his school did not bring him into contact with students who were long-time residents of the United States. Nor with white students, nor with affluent students, nor even with those who were on a more clearly upwardly-mobile trajectory. This segregation by race, class, and migration status is the norm in schools across the United States, and particularly in New York City, and it limits opportunities for newcomers and black and brown students particularly in building relationships that can help them to navigate their education and post-education futures (Alba, 2009; Kucsera \& Orfield, 2014; Reardon, 2011; Reynolds \& Crea, 2017; Schwartz \& Stiefel, 2011). In their comparative study of the education systems of five European nations and the U.S., Alba \& Holdaway (2013) reiterate the negative relationship between educational segregation and newcomer workforce participation, highlighting the ways in which the kinds of segregation by race, class, and immigration status that Moussa and his peers experienced can negatively impact later opportunities.

Following from this segregation, students at Moussa's school had more limited educational resources such as books or computers than students at wealthier schools (Darling-Hammond, 2010) and limited access to a college counselor, resulting in few opportunities to learn about the college admissions process (National College Access Network [NCAN], n.d.). Moussa explained that he did not apply for the Tuition Assistance Program, a form of financial aid in New York state, because "my high school, they never told me about it." Moussa also received support in his college application process far too late: "They gave us a mentor ... the same year we was supposed to 
graduate...four months or five months before. I didn't even knew what a personal statement was." The college admissions process may have seemed especially foreign to Moussa because it did not mirror the collaborative, project-based learning on which his school focused and which is identified in other literature, described above, as contributing to refugee students' success. The collaborative way he was taught to learn was counter to the kinds of individual tasks and assessments that make up college admissions. Moussa's school focused on education as a group undertaking, and yet the college admissions process was narrowly focused on individual products and outcomes, for which Moussa was not prepared at school and lacked outside mentors (see also, Jaffe-Walter \& Lee, 2011).

Moussa's experiences in his neighborhood were similarly segregated, and unequal. When he arrived in the Bronx, he described looking around and asking, "“What? Is this part of America?"” A 2007 New Years' trip to Times Square with his father marked the first and one of the only times Moussa felt as if he was in the America he expected. The neighborhood in the South Bronx where Moussa first lived because of the low cost of rent was riddled with gang violence and fights, a threatening environment for a newly arrived young black teenager. Reflecting on the trajectories of his classmates from high school, Moussa said: 'the parents was usually workin' 24/7, you know, and then most of [the kids] end up dead, most of them end up in jail."

Moussa's father, who had never had the chance to attend school himself, responded to the ever-present violence with a fierce sense of structure and control. He drove Moussa to and from school each day in the taxi where he earned his living rather than allowing him to traverse the streets alone. Moussa's father called frequently 
throughout the evening to enforce prayer, homework, and an early bedtime while shuttling passengers late into the night. Moussa quite contentedly focused on his schoolwork and the promise of where this hard work would take him. He explained that "I didn't have time to do no type of negativity outside of the house 'cause I barely had time for myself." Unlike in Guinea where he could sit under the streetlights to study, if he wanted to go outside in New York to play basketball or spend time in the neighborhood, his father insisted on accompanying him.

His father's Herculean efforts have kept Moussa physically safe. But, similar to his teachers, his father could not protect him from constant discrimination and violence. His black body, his West African origins, and his religion - Islam - have all earned him attention that was aggressive, exclusionary, and endlessly troubling. For Moussa, the U.S. has been more violent than Guinea. "Yes," he said, "I would say yes. It's more violent." In Guinea "most of the time you're afraid of the government... but here the people, the police, everybody's after you." Recently, three police cars pulled up and forced Moussa and a group of young men to the ground. Having just left the mosque, they were all wearing religious clothing from West Africa, long white or beige boubous, delicately embroidered at the front. That time, the evening ended peacefully, after the intervention of the local Imam. But Moussa knows that each and every evening, events could take a different turn. Moussa described his religion as an anchor of strength for him. He is hesitant, though, to pray or read the Qur'an in public. As he said, although Islam is “a peaceful religion," he is well aware that outward signs of Islam make people around him nervous, and he does not want to "cause myself trouble." 
A space to live the expected life

There was one space where, for Moussa, the promise of a different future in the U.S. lined up with reality. It was an afterschool program, designed especially for refugees and other new arrivals by an organization that had decades of experience working with refugees all over the world. Like other out-of-school time and afterschool programs, including historical settlement house programs for immigrant young people, this program provided a space to address educational needs, specific to the population, that were not addressed in schools (Addams, 2008 [1908]; Halpern, 2002). In this space, Moussa lived the life he had expected.

Moussa was first a student in the academic support classes of this program, which took place in his school building after the regular school day, on Saturdays, and during summer vacation. Moussa explained that the afterschool program "changed my life" through "helping me with my academic skill." This program was uniquely designed for students like Moussa who had been displaced early in their lives. It explicitly taught the building blocks of reading, understanding that many students' educational trajectories had been intermittent or severely curtailed. The students worked together at standing white boards on which well-trained teachers provided the needed basic reading support in which Moussa's regular day high school teachers had not been trained. Moussa described drawing pictures and transcribing words and practicing the multiplication skills he had never learned. Like his school, the afterschool program encouraged students to speak in their shared home languages to advance their understanding.

The teachers in this program also understood the emotional challenges of displacement and resettlement, and they purposefully created space to build and 
strengthen friendships, to engage parents through performances and other events, and for students to experience success and meaning by becoming leaders themselves. The afterschool program also assigned a case worker to each family to support them with other aspects of their resettlement, such as housing and health care. Moussa remembered staying for hours within this space, often until five or six o'clock at night, and his teachers - who he knew were volunteers - remained tireless and confident in their abilities to find success within each of their students. Moussa said that he never would have made it through high school without their targeted interventions.

Moussa then became a tutor with the same organization, charged with the success of other new arrivals. In this work, Moussa found a sense of belonging and purpose, which were a powerful antidote to his overall alienation. In particular, in this space and with these people, Moussa felt himself to be a leader. "They [were] the first people to give me a professional job" he said proudly. This work fulfilled his drive to make the world better. He described crouching down to help a small child from Nepal as the other children watched. Staring at Moussa, one whispered to the other that he wanted to be like Moussa — who this child described as being like Obama. The afterschool teacher overheard this comment and reiterated it, telling Moussa, “'see Moussa, people look up to you even if you don't know [it].'” Moussa felt a connection with newly-arrived refugees, many much younger than he was when he first came. He reflected on these moments of being knowledgeable, of being a leader, of finding a productive role for himself with satisfaction; being "able to be part of that, to help them was just amazing. It was very very-I feel good." 
After winning a high school essay competition, the afterschool program sent Moussa to Washington, D.C. for the inauguration of President Obama. He laughed as he described the application process: “I knew they weren't gonna leave me because I woulda' gone crazy, like, 'Nah you can't leave me for this one, I have to go!'” His plans to follow in Obama's footsteps were invigorated rather than diminished within the space of this program. At his graduation from the afterschool program, Moussa was asked to give a speech. His father joined the celebration and Moussa noted how proud his father was: "I've never seen him that happy." In this moment, Moussa fulfilled his father's hopes for him. His father told him: “Moussa, this is what I like. I don't like it when they call me in school and say 'Oh, your son is in trouble.' I want them to call me and say, 'Your son is giving a speech today'." Within this program, Moussa had a glimpse into what his life could be.

\section{A permanent exile}

Moussa's first job in this afterschool program was the first of many jobs in New York City, but he misses that initial work intensely. His current work is nothing like that work, which he loved. Could Moussa's education have better prepared him to create different post-graduation opportunities?

Moussa is now the family's breadwinner. His father lost his taxi license due to two unpaid tickets and, in his seventies, he is too old to seek other employment. His father apologizes to Moussa that Moussa must now head the household; this was not his plan. Yet Moussa said, "I am really proud of my father. I still see him as the man I want 
to be." He went on, "I don't want to be the reason for his sadness. He never made me sad."

Moussa dropped out of CCC five years ago when his father lost his job, and he has not been able to re-start his studies. He still cannot believe that he is not in school, shaking his head as he noted that "life really changed direction." Those around him imagined for him a more direct path to his imagined future as well. He explained that friends ask him “'Moussa, you're still not in school? Wow. That's crazy. If anyone thought - you? You not going to school, we can't believe it."' Moussa had enrolled in a two-year associate's degree in 2010, which was itself a compromise: he had long dreamed of a four-year college and had planned to attend a state university in upstate New York to study political science. But Moussa agreed to stay closer to home at his father's request and so he could "step up and help him."

Moussa described his life now as that of a "married man" despite being single. He works two jobs, six days a week to make ends meet for his family, which now includes a stepmother and young brother. He runs through his monthly expenses: $\$ 1090$ for a twobedroom apartment in the Bronx where they live; cable, food, gas, electricity, and smaller things like a Metrocard and haircuts. Moussa has adopted these responsibilities with grace. And he strayed between humor and seriousness in his descriptions of them: "I always have these jokes, 'oh, you know, October, November, December my paycheck look like a zip-code but in January [when business is slow] it look like my age'." Smiling briefly, he became serious again: "Right now I'm not making enough. There's just not enough." 
Moussa was clear that he does not enjoy his current work, at a restaurant downtown. The place is stately, old, and was a famous gathering place for abolitionists. Today, well-coifed white women chat delicately over afternoon cocktails; in the background a group of men jockey back and forth about their work. Parents and their daughters enter periodically, depositing money and photographing the garden in anticipation of upcoming wedding celebrations.

"How may I help you?" an older black man in a satin vest posed the question kindly to us and with the sophistication the surroundings seem to demand. This man knows Moussa well. "He's a good kid," he said. When Moussa emerged from the back of the restaurant, he looked downtrodden. He cautiously made eye contact, in contrast to the confidence with which he walked around his neighborhood.

At work, Moussa wears an all-black uniform, dusted with flour. He had not been given a satin vest like the bartender or the white apron of the waiters. Rather, his monochromatic outfit seemed intended to make him invisible, a silent responder to the needs of the clientele. As we stood at the front of the restaurant, the white manager approached in a silk, cream-colored suit, his greying hair and Eastern European accent giving him an otherworldliness. He explained that he too used to live in the Bronx as a child but left decades ago once he earned enough to move into the city. He then placed a heavy hand on Moussa's shoulder and asked him to return to work.

Moussa has worked at various stations in the restaurant's cavernous set of kitchens, hallways, and walk-in fridges over the four years of his employment. His roles have moved from the bowels of the restaurant - a stone-flanked tunnel that was once a part of the underground railroad - closer and closer to the first floor. He now fills butter 
dishes and prepares silverware at the threshold where kitchen and dining room meet. Echoing the past, a new kind of tango between confinement and freedom takes place here: Moussa and the other employees bus and wash dishes, cook and clean, stretching for a better life that seems increasingly illusive.

The small chalkboard which announces budding love, and the young white woman, likely a wedding planner who pops in every once in awhile to nervously check on arrangements, highlight the differences between this world and Moussa's. Moussa described his train ride to work, during which he sees the physical segregation between the haves and have-nots. As he explained, his commute back and forth to his job has revealed to him in stark relief the racial segregation of the city. At " $96^{\text {th }}$ street I see them [white people] all leaving out and then from there to the Bronx all I see is black people, Spanish people...that's how I know the type of social class I'm living in." He notes that he feels envious of the families who come here together, enjoying a weekend outing. In contrast, he and the other black and brown people he sees on the train "come here every day just to get money and go back to the ghetto." For Moussa, these physical barriers represent limitations that have been imposed on his life.

Moussa's father wishes he could go back to school. "He want me to go to school so bad," Moussa said, "but I'm telling him, 'You need to understand too... school it takes a lot... you have to focus when you're in school, you can't be working these long hours and then do good in school, you know?" Moussa drifted off, a sense of loss over him. Is the space he finds himself in a permanent exile to a future he both did not expect and cannot accept? At his afterschool program, Moussa felt in grasp of ways to overcome barriers of poverty, discrimination, and lack of opportunity. But now, having long left 
both the afterschool program and college, he sees these barriers more clearly, and they limit the opportunities he thought he might have.

\section{Relationships of support and hope}

Although Moussa must traverse a segregated American city in order to work, and although he faces prejudice at the restaurant from both customers and management, still, his life in low-paying jobs is punctuated by positive relationships that give him strength. These relationships are importantly different from the ones Moussa developed in school; rather than "false hope," these relationships enable for Moussa "material hope" (DuncanAndrade, 2009) in their acknowledgement of the material limitations that Moussa experiences and in providing him with concrete ways to address them. Unlike "wait citizenship" (Bellino, 2017), hope for the future is not contained in waiting and trying hard but rather in addressing structural limitations directly to create pathways toward the productive forms of citizenship that are connected to economic and educational opportunities.

Claudette, the former manager at the restaurant, for example, helped Moussa stay on track during his one fleeting year at CCC. She threatened not to give him any shifts if he did not do well in school, and insisted that Javier, an Ecuadorian math teacher who moonlights as a bus boy, provided him extra tutoring in the early morning hours before the restaurant opened. Moussa explained how Sam, the older black man in the satin vest, who has been working in the service industry for 35 years and yet is not allowed by the white owners to manage the bar himself, helps him to navigate the racism around him. Sam sometimes comes down hard on Moussa so as not to appear to favor him, but 
privately gives him encouragement: "He just tell me 'you just have to let it go, you know why they're doing it, but you need to understand one thing: you're at a position where you don't have enough power to go to war with these people, so you just have to get your money and forget about it." In Sam, Moussa receives counsel from a man who has long learned to make hard compromises to survive.

Of similar importance is the support Moussa gains from Bako, the Nigerian manager at the FedEx store where he works a second job with the goal of saving enough money to return to college. This "amazing" man is "like a father" to Moussa, also offering him guidance on how to survive in an unjust world. "If he see you without a belt he always tell you 'do not put your pants down here!"' Laughing, Moussa explained that, after this admonishment, "I used to wear a suit to go to FedEx every day!" In his relationship with Bako and within the FedEx workplace, Moussa sometimes glimpses the same opportunities he thought possible the last time he wore his suit regularly, at school and in the afterschool program. This job feels less like a barrier between the future he imagines and his current life, and more like a step to get there, in particular because here, Moussa feels that he is learning. It is not like the restaurant, where the work feels like a constant humiliation. "I don't want a job where I have to wake up every morning and do the same thing. I want a job where I wake up, doing this and then move to the next, something that will push you forward." Moussa feels that the FedEx job is giving him these opportunities, teaching him computer skills and how the postal system works, and the money he makes at the FedEx he keeps separate, as his savings to re-enter college. Here, Moussa also experiences respect, as Bako allows him to deposit the FedEx's 
earnings at the bank at the end of the day and gave him space to do his homework before he dropped out of CCC.

"I want to get that degree," Moussa said emphatically. In particular, his goal is still to study political science, with his once-upon-a-time goal in mind, to follow in the footsteps of great black leaders. In his own homemade video, he has a clear plan about how he might one day lead his homeplace of Guinea.

The video is a cartoon of sorts with a hopeful and nostalgic sound track. First, a hazy picture of Conakry, Guinea's capital, framed by text: "World Largest production of Bauxite" and the qualification "One Of The Poorest Nation On Earth." On the next screen is a map, locating Guinea in West Africa. And then, as the background music picks up speed, more shots: a picture of an abandoned school building, a hill gouged by mining, a fish market, a congested classroom full of children in green uniforms, a man covered in blood with a soldier behind him. Each image is accompanied by a line that together seem to make up a poem of promise squandered:

Social Collapsed Institutions

Only Nation That Don't Benefit From It's Own Natural Resources.

Lack Of Education, Overcrowding Classroom

Human Rights Are Not Respect.

The Regime Of All 4 Man [4 Presidents since Independence]

Was Defined By Corruption + Violence

And then, a photo of Moussa, from the speech he gave in the afterschool program. In his black suit, as he did as a teenager, he holds forth as a leader:

As a President of Guinea 
I Will Build Roads

I will Have A Plan That Will

Promote More Affordable Housing

I will Launch The Largest Clean Water

Project That the World Have Ever Seen.

I Will Fights Against

Poverty; Hunger; And Disease

I Will Also Make Sure People

Have Universal Health care.

I Will Limit Our Import On Goods

We Will be Self sufficient.

I Will Change How

The World Sees Us.

VOTE FOR MOUSSA DIALLO 2020

Moussa explained his purpose in making this video: "I feel like I went through a lot in life and maybe by sharing it I can help another who's going through the same struggle as me understand that no matter how bad a situation seem today there's always hope for creating a better tomorrow." Moussa enacts the "multidirectional aspirations" that Bajaj and Bartlett describe as a useful aim of education for refugee students (2017). These aspirations, however, are dealt blows every day through the immense hurdles that he confronts and is discouraged by: the violence that surrounds him and creates fear, the discrimination he experiences at work, the segregation of the city where he lives, the financial barriers that prevent his re-enrollment in college despite good grades. In the face 
of these structural barriers, Moussa holds onto this ultimate hope of resettlement, that if he continues to work hard, to put his mind to it, he will go back to college, he will succeed there, he will graduate and get a good job, and he will indeed follow in the footsteps of great black men he so admires, becoming the leader others have seen in him.

\section{Discussion}

The future that Moussa stands to inherit is very different from the one he seeks to create. Moussa expressed a sense of regret about his education, remarkably not as much for himself as for his peers. He said, "Eighty percent are not doing well, eighty percent are not studying. If you look, none of the kids from [our school] are doing well. I can never forgive the school for that." What would we do as Moussa's and his peers' teachers now, with a better grasp on their once unknowable futures? In this section, we seek to explore some of the ways in which schools and teachers might re-tool themselves to better meet the long-term needs of their resettled refugee students.

There are very tangible elements of support that his school and his teachers provided, which Moussa identified as being critical for him post-graduation. Moussa learned English, built strong academic skills, and graduated. Post-graduation, Moussa thus had the credentials to enroll in college (albeit not the one he would have chosen), and he achieved good grades once there. Moussa's high school also enabled him to connect to a group of peers with similar experiences, who were a source of support and a counter to the isolation he often felt in his neighborhood. He developed caring relationships with a few teachers who helped him to develop his confidence as a learner. All of these elements echo the literature on school structures and practices that foster 
refugee students' success (for example, Bajaj \& Bartlett, 2017; Bartlett et al., Forthcoming; Fine \& Jaffe - Walter, 2007; Fine et al., 2005; Mendenhall et al., 2017).

As most secondary schools are, Moussa's school was mostly disconnected from his family. His father was more involved than most parents, attending parent-teacher conferences and school events. Yet invisible to the school was just how connected Moussa's post-graduation trajectory was to the employment trajectory of his father. Better connecting refugees to sources of financial aid is a relatively straight-forward strategy for schools, and yet a more transformative shift may be engaging schools in family-level planning, training, and networking related to employment, as Moussa's afterschool program did.

The relationships that Moussa developed post-graduation, particularly in the workplace with older black and brown men and women, provided him with a different kind of learning that he did not gain from his school. Our methodology, which examined Moussa's post-graduation experiences, allowed us to see how important this learning has been, and how it was missing from his school experiences. Moussa's high school prompted him to develop an academic critical perspective on social inequalities in the U.S., but only after graduation, and through these relationships, did he begin to apply this lens to his experiences and interactions. Moussa's teachers, largely white and in their early years of teaching, taught him about inequality broadly, but they were not equipped to teach him how to respond to the inequalities that he experienced. Both his father and his school taught Moussa to engage in avoidance behavior in order to stay clear of the physical violence around him. Unlike the students in Bajaj and Bartlett's study, he was not "socialized... into active participation" in his community (2017, p. 31). He stayed 
inside at night to ensure that he did not interact with the police, and he prayed discretely to avoid anti-Muslim discrimination. Yet, post-graduation, Moussa came face-to-face with the structural violence that, when avoided, keeps him in the dead-end jobs with which he is so frustrated. In the kitchen of his fancy restaurant workplace, Moussa remains invisible, again safe from physical harm but avoiding the inequalities that prevent him from achieving his aspirations.

From experiences in his afterschool program, Moussa expected that he could create a future in which he would be a leader. He loved the feeling of being productive, of having, as he called it, a "professional job," teaching refugee children, as he had been taught. It was an aspiration he had nurtured, and truly believed in, from exile in Guinea, working under the streetlights, and in New York City at his small school. Yet he is now four years out of school, without a college degree, in jobs that make him feel purposeless, and barely making ends meet for his family.

More than his high school teachers were able to do, the people Moussa has built close relationships with in his adult life are ones who are helping him to see the structures that constrain him and offer him guidance to negotiate them, rather than assuming they will cease to exist when he checks the boxes of good grades, graduation, and good kid. Despite their efforts, these barriers remain insurmountable, circumscribed by boxes that Moussa and most other refugees cannot check: financial security, housing security, freedom from violence and discrimination, critical awareness of unequal opportunity structures, and more and different skills to navigate them. These barriers are pernicious, not only for refugees, but across the segregated communities in which they reside. For resettled refugees to traverse education into post-graduation opportunities, teachers of 
refugees must be better equipped to act on these issues and to support their students to do the same.

There are important ways in which schools that serve refugee young people can align students' in-school experiences with the realities that they may face post-school. These include recruiting more teachers who are themselves refugees and immigrants and who can, from personal experience and learning, help newcomer young people to navigate racial discrimination, xenophobia, and poverty. Teachers must also be equipped to discuss and respond to the structural inequalities that many refugees experience in their places of resettlement. Refugees, by definition, have fled from conflict and persecution; and yet for many refugees, the systems and structures of racism and inequality that confront them in the U.S. are different from what they experienced prior to arrival. Educators must be prepared to talk to newly arrived refugees about these dynamics and to engage with the resulting material constraints that shape their lives. Rather that the "false hope" that characterizes the narrative of refugee resettlement, teachers can employ a “critical pedagogy," through which educators and students "critique notions of equal opportunity and access" (Duncan-Andrade \& Morrell, 2008, p. 10). Importantly, teachers can create opportunities for students to practice the work involved in engaging and dismantling the unequal power structures that shape students' in-school, out-of-school, and post-school lives. This approach also includes working with students and families together to develop strategies for meaningful employment for parents and students and access to resources such as college financial aid. Newly arrived refugee students also need the opportunity to interact with long-time residents and U.S.-born peers, building networks and the kinds of social capital that can support post-school opportunities. 
The importance of structuring schooling to support students both in and after school is not only relevant for refugees. Yet for refugees - for whom the U.S. is a new context to navigate and who have few relationships of support in this new context - the kinds of learning that school can provide are unique in helping them to navigate their post-school lives. Nor is the need to prepare refugee students for post-school experiences unique to the U.S.: as the number of refugees in schools in Europe and around the world continues to increase, teachers will be challenged to provide supportive in-school environments, and to equip students to be able to use that education for the productive trajectories for which they have prepared and planned. Teachers of refugees must increasingly develop a "critical hope" (Duncan-Andrade, 2009) for refugee newcomers, merging academic skills with relationships of trust, hope with material strategies for success, and opportunities to navigate, critique and eventually transform the structural barriers they confront.

\section{Notes}

${ }^{1}$ The two authors have contributed equally to this article and are listed in alphabetical order.

${ }^{2}$ All names have been changed to protect the identities of research participants.

\section{References}

Addams, J. (2008 [1908]). The Public School and the Immigrant Child. In D. J. Flinders \& S. J. Thornton (Eds.), The curriculum studies reader (pp. 25-27). New York: Routledge.

Alba, R. (2009). Blurring the color line: the new chance for a more integrated America. Cambridge, Mass.: Harvard University Press. 
Alba, R., \& Foner, N. (2014). Comparing Immigrant Integration in North America and Western Europe: How Much Do the Grand Narratives Tell Us? International Migration Review, 48(s1), S263-S291. doi:10.1111/imre.12134

Alba, R., \& Holdaway, J. (Eds.). (2013). The children of immigrants at school: A comparative look at integration in the United States and Western Europe. New York, NY: NYU Press.

Anderson-Levitt, K. M., \& Diallo, B. B. (2003). Teaching by the Book in Guinea. In K. M. Anderson-Levitt \& A. American Anthropological (Eds.), Local meanings, global schooling : anthropology and world culture theory. New York.

Auernheimer, G. (2005). The German Education System: Dysfunctional for an Immigration Society. European Education, 37(4), 75-89. doi:10.2753/EUE10564934370406

Bajaj, M., \& Bartlett, L. (2017). Critical transnational curriculum for immigrant and refugee students. Curriculum Inquiry, 47(1), 25-35.

doi:10.1080/03626784.2016.1254499

Bartlett, L., \& García, O. (2011). Additive schooling in subtractive times : bilingual education and Dominican immigrant youth in the Heights. Nashville: Vanderbilt University Press.

Bartlett, L., Mendenhall, M., \& Ghaffar-Kucher, A. (Forthcoming). Culture in acculturation: Refugee youth's schooling experiences in international schools in New York City. International Journal of Intercultural Relations. doi:http://dx.doi.org/10.1016/j.ijintrel.2017.04.005

Bellino, M. J. (2017). Youth in postwar Guatemala : education and civic identity in transition. New Brunswick, NJ: Rutgers University Press.

Benson, C., \& Lynd, M. (2011). National languages in education in Guinea-Conakry: reemancipation in progress. International Journal of the Sociology of Language, 2011(209), 113-129. doi:10.1515/IJSL.2011.024

Betancourt, T. S., Meyers-Ohki, S. E., Charrow, A. P., \& Tol, W. A. (2013). Interventions for Children Affected by War: An Ecological Perspective on Psychosocial Support and Mental Health Care. Harvard review of psychiatry, 21(2), 70-91. doi:10.1097/HRP.0b013e318283bf8f

Betancourt, T. S., Newnham, E. A., Layne, C. M., Kim, S., Steinberg, A. M., Ellis, H., \& Birman, D. (2012). Trauma History and Psychopathology inWar-Affected Refugee Children Referred for Trauma-Related Mental Health Services in the United States. Journal of Traumatic Stress, 25, 682-690. doi:10.1002/jts.21749

Bigelow, M. (2010). Mogadishu on the Mississippi : language, racialized identity, and education in a new land. Chichester, West Sussex, U.K. ; Malden, MA: WileyBlackwell.

Buck, P., \& Silver, R. (2012). Educated for change? : Muslim refugee women in the west. Charlotte, N.C.: Information Age Pub.

Capps, R., \& Newland, K. (2015). The Integration Outcomes of U.S. Refugees: Successes and Challenges. Retrieved from Washington, DC:

http://www.migrationpolicy.org/research/integration-outcomes-us-refugeessuccesses-and-challenges

Darling-Hammond, L. (2010). The flat world and education : how America's commitment to equity will determine our future. New York: Teachers College Press. 
Devictor, X., \& Do, Q.-T. (2016). How Many Years Have Refugees Been in Exile? Retrieved from Washington, DC:

Dryden-Peterson, S. (2010). Bridging Home: Building Relationships Between Immigrant and Long-Time Resident Youth. Teachers College Record, 112(9), 2320-2351.

Dryden-Peterson, S. (2011). Refugee Children Aspiring toward the Future: Linking Education and Livelihoods. In K. Mundy \& S. Dryden-Peterson (Eds.), Educating Children in Conflict Zones: Research, Policy, and Practice for Systemic Change (A Tribute to Jackie Kirk) (pp. 85-99). New York: Teachers College Press.

Dryden-Peterson, S. (2015). Refugee education in countries of first asylum: Breaking open the black box of pre-resettlement experiences. Theory and Research in Education, 14(2), 1-18.

Dryden-Peterson, S. (2017a). Family-school relationships in immigrant children's wellbeing: the intersection of demographics and school culture in the experiences of black African immigrants in the United States. Race Ethnicity and Education, 117. doi:10.1080/13613324.2017.1294562

Dryden-Peterson, S. (2017b). Refugee education: Education for an unknowable future. Curriculum Inquiry, 47(1), 14-24. doi:10.1080/03626784.2016.1255935

Duncan-Andrade, J. (2009). Note to Educators: Hope Required When Growing Roses in Concrete. Harvard Educational Review, 79(2), 181-194. doi:10.17763/haer.79.2.nu3436017730384w

Dyer, C. (1999). Researching the Implementation of Educational Policy: a backward mapping approach. Comparative Education, 35(1), 45-61.

Fine, M., \& Jaffe-Walter, R. (2007). Swimming: On Oxygen, Resistance, and Possibility for Immigrant Youth under Siege. Anthropology \& Education Quarterly, 38(1), 76-96. doi:10.1525/aeq.2007.38.1.76

Fine, M., Stoudt, B., \& Futch, V. (2005). A Quantitative and Qualitative Cohort Analysis of Graduation and Dropout Rates: Teaching and Learning in a Transcultural Academic Environment. Retrieved from New York:

Flyvbjerg, B. (2006). Five Misunderstandings About Case-Study Research. Qualitative Inquiry, 12(2), 219-245. doi:doi:10.1177/1077800405284363

Freire, P. (1994). Pedagogy of hope : reliving Pedagogy of the oppressed. New York: Continuum.

Garcĺa, O., \& Wei, L. (2014). Translanguaging: Language, Bilingualism and Education. London: Palgrave Macmillian UK.

Gilmore, R. W. (2011). What is to be done? American Quarterly, 63(2), 245-265.

Goren, H., \& Yemini, M. (2015). Global citizenship education in context: teacher perceptions at an international school and a local Israeli school. Compare: A Journal of Comparative and International Education, 1-22. doi:10.1080/03057925.2015.1111752

Goren, H., \& Yemini, M. (2017). Citizenship education redefined - A systematic review of empirical studies on global citizenship education. International Journal of Educational Research, 82, 170-183. doi:10.1016/j.ijer.2017.02.004

Halpern, R. (2002). A different kind of child development institution: The history of after-school programs for low-income children. Teachers College Record, 104(2), 178-211. 
Hatoss, A., \& Huijser, H. (2010). Gendered barriers to educational opportunities: resettlement of Sudanese refugees in Australia. Gender \& Education, 22(2), 147160. doi:10.1080/09540250903560497

Hornberger, N. H., \& Link, H. (2012). Translanguaging and transnational literacies in multilingual classrooms: a biliteracy lens. International Journal of Bilingual Education and Bilingualism, 15(3), 261-278. doi:10.1080/13670050.2012.658016

Jaffe-Walter, R., \& Lee, S. J. (2011). "To Trust in My Root and to Take That to Go Forward": Supporting College Access for Immigrant Youth in the Global City. Anthropology \& Education Quarterly, 42(3), 281-296. doi:10.1111/j.15481492.2011.01132.x

Jones, D. (2006). Education in Complex Emergencies: A Case Study of the IRC Guinea Education Program. (Masters of Arts in Law and Diplomacy), Tufts University, Medford, MA. Retrieved from http://toolkit.ineesite.org/toolkit/INEEcms/uploads/1089/Education_Complex_Em erg Case Study IRC Guinea.pdf

Kowalczyk, J. (2010). "The Immigration Problem" and European Education Reforms. European Education, 42(4), 5-24. doi:10.2753/EUE1056-4934420401

Kucsera, J., \& Orfield, G. (2014). New York State's Extreme School Segregation Inequality, Inaction and a Damaged Future. Retrieved from Los Angeles:

Lamba, N. K. (2003). The Employment Experiences of Canadian Refugees: Measuring the Impact of Human and Social Capital on Quality of Employment. Canadian Review of Sociology and Anthropology, 40(1), 45-64.

Lamont, M., \& Swidler, A. (2014). Methodological Pluralism and the Possibilities and Limits of Interviewing. Qualitative Sociology. doi:DOI 10.1007/s11133-0149274-Z

Lawrence-Lightfoot, S. (2005). Reflections on Portraiture: A Dialogue Between Art and Science. Qualitative Inquiry, 11(1), 3-15.

Lawrence-Lightfoot, S., \& Davis, J. H. (1997). The Art and Science of Portraiture. San Francisco: Jossey-Bass.

Marchal, R. (2002). Liberia, Sierra Leone, Guinea: a war without borders? Politique africaine, 88, 5-12.

McBrien, J. L. (2005). Educational needs and barriers for refugee students in the United States: A review of the literature. Review of Educational Research, 75(3), 329364.

Mendenhall, M., Bartlett, L., \& Ghaffar-Kucher, A. (2017). "If You Need Help, They are Always There for us": Education for Refugees in an International High School in NYC. The Urban Review, 49(1), 1-25. doi:10.1007/s11256-016-0379-4

Migration Policy Institute. (2014). Refugee Resettlement in the United States: Outcomes and Challenges. Retrieved from Washington, DC:

National College Access Network [NCAN]. (n.d.). Why college access \& successs? Stark college attainment gaps by race and income. Retrieved from Washington, DC: http://www.collegeaccess.org/Why College Access Success

New York City Department of Education. (2017). New York City Graduation Rates Class of 2016 (2012 Cohort). Retrieved from New York:

Nunn, C., McMichael, C., Gifford, S. M., \& Correa-Velez, I. (2015). Mobility and security: the perceived benefits of citizenship for resettled young people from 
refugee backgrounds. Journal of Ethnic and Migration Studies, 1-18. doi:10.1080/1369183X.2015.1086633

Rawlence, B. (2016). City of thorns : nine lives in the world's largest refugee camp (First U.S. edition. ed.). New York: Picador.

Reardon, S. (2011). The widening academic achievement gap between the rich and the poor: New evidence and possible explanations. In G. J. Duncan \& R. J. Murnane (Eds.), Whither opportunity? : rising inequality, schools, and children's life chances (pp. 91-116). New York; Chicago: Russell Sage Foundation; Spencer Foundation.

Reilly, J., \& Niens, U. (2014). Global citizenship as education for peacebuilding in a divided society: structural and contextual constraints on the development of critical dialogic discourse in schools. Compare: A Journal of Comparative and International Education, 44(1), 53-76. doi:10.1080/03057925.2013.859894

Reynolds, A. D., \& Crea, T. M. (2017). The Integration of Immigrant Youth in Schools and Friendship Networks. Population Research and Policy Review, 1-29. doi:10.1007/s11113-017-9434-4

Schwartz, A. E., \& Stiefel, L. (2011). Immigrants and inequality in public schools. In G. J. Duncan \& R. J. Murnane (Eds.), Whither opportunity? : rising inequality, schools, and children's life chances (pp. 419-442). New York; Chicago: Russell Sage Foundation; Spencer Foundation.

Sévigny, C. A. (2012). Starting from refugees themselves: towards an institutional ethnography of resettlement. Retrieved from Geneva:

Shepler, S. (2011). "Helping our children will help in the reconstruction of our country": Repatriated refugee teachers in post-conflict Sierra Leone and Liberia. In K. Mundy \& S. Dryden-Peterson (Eds.), Educating Children in Conflict Zones: Research, Policy, and Practice for Systemic Change (A Tribute to Jackie Kirk) (pp. 199-217). New York: Teachers College Press.

Swing, W. L. (2017). Practical considerations for effective resettlement. Forced Migration Review, 54(1), 4-6.

UNHCR. (2010). Convention and Protocol Relating to the Status of Refugees Retrieved from Geneva:

UNHCR. (2014a). Facts and Figures about Refugees. Retrieved from http://www.unhcr.org.uk/about-us/key-facts-and-figures.html

UNHCR. (2014b). Resettlement: A New Beginning in a Third Country. Retrieved from http://www.unhcr.org/pages/4a16b1676.html

UNHCR. (2015). UNHCR Statistical Yearbook 2014. Retrieved from Geneva:

United States Department of Education. (2016). The state of racial diversity in the educator workforce. Retrieved from Washington, DC: https://www2.ed.gov/rschstat/eval/highered/racial-diversity/state-racial-diversityworkforce.pdf 